\title{
KEMEJA (KEMAH KERJA SEJARAH) SEBAGAI MODEL PEMBELAJARAN SEJARAH YANG AKTIF, INOVATIF, KREATIF, EFEKTIF, DAN \\ MENYENANGKAN
}

\author{
Muhammad Hanif ${ }^{*}$ )
}

\begin{abstract}
Abstrak
Pembelajaran sejarah masih dilingkupi oleh berbagai stereotip negatif seperti membosankan, bertele-tele dan tidak relevan dengan konteks sosial peserta didik. Relevansi penyajian materi sejarah dengan situasi sosial peserta didik sering dipertanyakan. Kondisi itu mengisyaratkan semakin pentingnya pembelajaran sejarah yang kontekstual sehingga terbangun suasana pembelajaran sejarah yang aktif, inovatif, kreatif, efektif, dan menyenangkan.

Penelitian ini bertujuan untuk mengungkap kemah kerja sejarah sebagai model pembelajaran sejarah yang aktif, inovatif, kreatif, efektif, dan menyenangkan. Penelitian dilakukan di Program Studi Pendidikan Sejarah IKIP PGRI MADIUN. Jenis penelitian deskriptif kualitatif. Data diperoleh dari sumber primer dan sekunder berupa keterangan atau fakta dari informan, dan peristiwa atau aktivitas serta dokumen dan arsip tentang yang relevan. Pengumpulan data primer dilakukan dengan teknik wawancara mendalam dan observasi langsung. Sampel informan dipilih secara selektif dan mengalir. Validasi data melalui triangulasi sumber dan teknik. Analisis data dengan analisis interaktif.

Hasil penelitian menunjukkan bahwa rancangan model Kemeja terdiri dari empat komponen kegiatan utama, yaitu persiapan, pelaksanaan, evaluasi, refleksi, dan pelaporan. Tahap persiapan meliputi persiapan di kampus dan di lapangan, baik teknis maupun non teknis. Tahap pelaksanaan terdiri dari tiga kegiatan, yaitu klarifikasi dan eksplorasi objek, social mapping, debat mahasiswa, dan pertunjukkan seni. Model Kemeja potensial untuk menjadi alternatif pembelajaran sejarah yang aktif, inovatif, kreatif, efektif, dan menyenangkan.
\end{abstract}

Kata kunci: kemah kerja, model pembelajaran sejarah

* Muhammad Hanif adalah Dosen Program Studi Pendidikan Sejarah IKIP PGRI Madiun 11|Agastya Vol. 02 No. 02, JULI 2012 


\section{Pendahuluan}

Pengajaran sejarah kan aktivitas penting kehidupan berbangsa dan bernegara. Pengajaran sejarah memiliki fungsi fundamental, tidak saja dalam pembangunan kepribadian nasional beserta identitas dan jati diri bangsa, melainkan juga pembangunan kualitas manusia dan masyarakat suatu bangsa (Djoko Suryo, 1993: 3). Pengajaran sejarah berperan penting dalam pembangunan karakter dan identitas kolektif suatu bangsa atau identitas nasional. Terhapusnya masa lampau dari ingatan kolektif suatu bangsa berakibat pada hilangnya identitas. Seorang warga bangsa yang kehilangan ingatan terhadap sejarah bangsanya akan kehilangan identitasnya, dengan akibat tidak dapat berkomunikasi dengan orang lain atau paling sedikit akan menjadi kacau pembawaannya (Sartono Kartodirdjo, 1999: 18).

Melalui pengajaran sejarah akan dapat ditemukan bahwa setiap peristiwa sejarah selalu berkaitan dengan peristiwa sejarah lainnya pada kurun waktu tertentu, yaitu antara peristiwa lokal, nasional, regional, dan internasional. Setiap peristiwa sejarah tidak berdimensi tunggal, melainkan merupakan hasil interaksi dari berbagai kekuatan atau faktor-faktor sosial, politik, ekonomi, budaya, dan geografis.

Salah satu indikator pengajaran sejarah yang berhasil adalah mampu menjadikan peserta didik tertarik dan semakin bersemangat dalam belajar sejarah. Gambaran dan kebutuhan masyarakat di masa kini dan masa depan bagi peserta didik harus dipahami oleh pendidik. Gambaran dan kebutuhan masyarakat di masa depan tentu saja tidak dapat dijelaskan sepenuhnya, namun ada beberapa aspek yang dapat diketahui dan diperkirakan sebagai gambaran untuk mempersiapkan peserta didik Menghadapi tantangan zamannya. Terkait dengan hal tersebut, maka interaksi antara hasil belajar yang diharapkan dengan kondisi belajar yang dibutuhkan menjadi penting untuk diperhatikan (Gustavson dalam Hariyono, 1995: 155).

Kenyataanya, pengajaran sejarah saat ini masih dilingkupi oleh berbagai stereotip negatif. Pengajaran sejarah dinilai membosankan karena penyajiannya berteletele dan untuk menguasainya dibutuhkan kemampuan menghafal yang luar biasa.

Stereotip yang kurang mengesankan tersebut disebabkan oleh produksi masa lampau yang dalam penyajiannya tidak relevan dengan konteks sosial peserta didik. Masalah kontekstualisme ini diperkuat dengan kejenuhan mental dalam mengejar tuntutan pemenuhan kurikulum, yakni menguasai sejumlah materi yang tersajikan dalam berbagai bahan ajar. Peserta didik hanya memiliki sedikit waktu untuk melakukan interaksi sosial.

Relevansi penyajian materi sejarah dengan situasi sosial peserta didik sering menjadi bahan pertanyaan. Mereka harus berpikir dua kali untuk mengasosiasikan materi yang dipelajari dengan kenyataan hidupnya. Keterlambatan dalam menginternalisasi materi pun terjadi. Konsep siswa baru pada tahap asosiasi, tetapi 
masa belajarnya telah habis. Peserta didik enggan melanjutkan hal itu lagi karena dibatasi oleh waktu dan harus beralih ke materi lain.

Stereotip negatif mempengaruhi minat dan motivasi belajar peserta didik. Pengetahuan pendidik akan situasi-situasi sosial aktual yang tengah berlangsung dalam masyarakat juga mempengaruhi minat dan motivasi peserta didik. Pendidik kurang mampu menghubungkan relevansi materi sejarah dengan kenyataan praktis dan keterkaitannya dengan ilmu-ilmu lain dalam mengeksplorasi bahan pembelajaran. Selain itu, situasi dan kondisi belajar kurang variatif juga akan mengurangi gairah belajar peserta didik.

Berbagai indikasi negatif tentang pengajaran sejarah merupakan persoalan krusial yang perlu segera dicari pemecahan yang harus ditempuh dalam pembelajaran. Menurut Nu'man Sumantri (1996:34), setidaknya ada tiga masalah pokok yang melatarbelakangi keengganan peserta didik dalam mempelajari ilmu pengetahuan sosial, termasuk sejarah. Pertama, masalah teknik pembelajaran yang tidak menumbuhkan motivasi peserta didik. Seharusnya, proses pembelajaran itu dapat memacu keingintahuan peserta didik untuk membedah masalah-masalah seputar lingkungan sosialnya sekaligus dapat membentuk opini pribadi terhadap masalah-masalah tersebut. Di sini, mereka bukan lagi dianggap sebagai tabula rasa, kertas kosong atau pribadi yang menerima secara pasif sajian yang tidak tepat sasaran, pribadi yang tidak mengetahui apaapa, melainkan pribadi yang telah berinteraksi dengan lingkungan dan berhak untuk mengkonstruksi pengetahuannya sendiri.

Kedua, eksistensi guru bukan sebagai fasilitator yang membelajarkan, melainkan pribadi yang mengajar atau menggurui. Jika hal ini menjadi prioritas dalam pembelajaran, maka kesan negatif yang bisa mematikan kreativitas peserta didik pun timbul, bahwa guru itu sumber ilmu sementara peserta didik adalah gudangnya. Peserta didik adalah bank dan pendidik adalah nasabahnya. Pendidik menabung ilmu dalam banknya adalah peserta didik, seperti dikritik oleh Paulo Freire dengan menyebutnya sebagai model banking system (Paulo Freire, 1984:11).

Peran aktif peserta didik dalam mengeksplorasi dan mengkonstruksi pengetahuannya semestinya diutamakan. Pendidik memfasilitasi peserta didik untuk mengikuti pola-pola kognitif dan memperlihatkan konsep pengetahuannya dapat berlaku untuk setiap keadaan. Peserta didik membentuk konsep melalui proses asimilasi dan akomodasi, sedangkan pendidik menunjukkan kebenaran konsep pengetahuan tersebut dengan hukum, teori dan kebenaran yang berlaku umum. Jika yang diperoleh peserta didik adalah ketidaksesuaian, maka pendidik dapat menunjukkan kesalahan konsep itu dan memperlihatkan yang benar, atau membantu berargumen, bukti dan referensi ilmiah untuk mengkonstruksi pengetahuan baru. Yang diharapkan dari pendidik adalah menguasai ketrampilan profesional dan unjuk kerjanya, membuat skenario pembelajaran yang menge- 
sankan dan memacu keingintahuan peserta didik, serta melatih kemampuan berpikir dan berinteraksi peserta didik secara benar.

Ketiga, penyampaian pesan pembelajaran dengan media yang kurang interaktif dan dialogis. Yang diharapkan dari peserta didik adalah merasa menyenangi materi, merasa membutuhkan ilmu itu serta dapat melaksanakan pesan pembelajaran. Peserta didik dapat menerjemahkan isi pesan itu ke dalam ranah-ranah kognitif karena dari situlah sumber kompetensi baginya dan haluan evaluasi bagi pendidik. Peserta didik dapat memiliki keahlian afektif dan psikomotorik yang bisa diukur. Dalam konteks inilah diperlukan inovasi dalam metode pembelajaran sejarah.

Pembelajaran pada dasarnya berusaha membantu seseorang memperoleh atau mengubah perilaku. Untuk itu yang perlu diperhatikan salah satunya adalah metode pembelajaran. Metode pembelajaran yang dapat digunakan semestinya mampu mengoptimalkan penanaman nilainilai dan karakter karena sejarah sarat akan nilai-nilai pembangun karakter. Penanaman nilai dan karakter yang tidak sepenuhnya mampu diterima secara baik oleh peserta didik dapat mengakibatkan disintegrasi kultural. Peserta didik sebagai calon pewaris kebudayaan dan sejarah mengalami kebekuan dan kehilangan orientasi dengan generasi sebelumnya. Ikatan historis antar generasi tersebut dapat terputus sehingga kehilangan jalinan emosi dengan sejarah bangsa ini.

Penanaman nilai sejarah pada hakikatnya dapat dipersatukan deng- an baik jika ada usaha kreatif dari masyarakat, pemerintah, dan pihak penyelenggara pendidikan untuk memanfaatkan momen dan media apa saja agar kedua unsur itu dapat diterima tanpa membebani peserta didik.

Masalah tersebut di atas mengisyaratkan kepada para pendidik perlunya membangun minat sebelum pendidik menumbuhkembangkan sikap tertentu dan pengalaman belajar yang mengembangkan kemampuan kognitif, atau afektif, Atau psikomotorik. Pembelajaran sejarah dapat dirancang dalam suasana informal, rekreatif, dan kontekstual. Pembelajaran lebih menekankan pada proses keterlibatan peserta didik secara penuh untuk

Dapat menemukan materi yang dipelajari dan mengubungkan dengan situasi kehidupan nyata sehingga Dapat menerapkan dalam kehidupan nyata (Wina Sanjaya. 2008:255).

Di tingkat perguruan tinggi, pembelajaran sejarah yang konteksTual semakin diperlukan karena tuntutan mahasiswa untuk segera mampu mengaktualisasikan bekal keilmuannya di masyarakat, terlebih bagi mahasiswa calon guru sejarah. Pendekatan kontekstual akan membangun suasana pembelajaran sejarah yang aktif, inovatif, kreatif, dan efektif dalam suasana yang menyenangkan.

Salah satu bentuk model pembelajaran untuk membangun suasana tersebut di atas adalah model kemah kerja sejarah, disingkat Kemeja. Kemeja dimasudkan sebagai Suatu kegiatan sebagaimana yang dilakukan oleh kegiatan kepramukaan, yaitu kegiatan di alam terbuka 
untuk beberapa hari antara pendidik dengan peserta didik dan berdiam dalam kemah atau suatu rekreasi yang bersifat edukatif yang dilaksanakan di alam terbuka dengan berbagai metode yang menyenangkan. Pembelajaran dilakukan dalam bentuk interaktif antara pendidik (dosen) dengan peserta didik (mahasiswa), dan lingkungan.

Model Kemeja dapat menjawab paradigma bahwa sejarah bukanlah pelajaran hafalan. Kemeja akan mampu mendialogkan antara materi di dalam kelas dengan kenyataan yang sebenarnya di masyarakat. Dosen mengajak mahasiswa terlibat langsung dengan realitas dan berdialog dengan masyarakat sebagai narasumber pembelajaran sejarah. Sejarah sebagai praktik akan lebih menyenangkan bagi mahasiswa untuk belajar, apalagi disertai dengan unsur rekreatif. Dengan demikian pembelajaran sejarah menjadi lebih hidup dan bermakna.

Penelitian ini akan mengungkap kemah kerja sejarah sebagai model pembelajaran sejarah yang aktif, inovatif, kreatif, efektif, dan menyenangkan sehingga pembelajaran dapat lebih bermakna bagi peserta didik.

Berdasarkan uraian di atas, maka rumusan masalah dalam penelitian ini sebagai berikut, "Bagaimanakah rancangan Kemeja sebagai model pembelajaran sejarah yang aktif, inovatif, kreatif, efektif, dan menyenangkan bagi mahasiswa?"

\section{Tujuan dan Manfaat Penelitian}

Berdasarkan rumusan masalah, maka tujuan penelitian akan merumuskan rancangan Kemeja sebagai model pembelajaran sejarah yang aktif, inovatif, kreatif, efektif dan menyenangkan bagi mahasiswa.

Penelitian ini penting dilakukan sebagai bahan masukan bagi para dosen pendidikan sejarah dalam merancang dan mengembangkan model pembelajaran yang aktif, inovatif, kreatif, efektif dan menyenangkan.

\section{Tinjauan Pustaka}

\section{A. Pembelajaran Sejarah}

Setiap generasi selalu memandang masa lampau dengan sudut pandangnya sendiri. Pandangan terhadap masa lampu menciptakan kembali gambaran tentang masa lampu tersebut yang disesuaikan dengan pola pikirnya. Segala peristiwa masa lampau yang berkaitan dengan kehidupan manusia menjadi penting artinya sebagai pedoman pada masa kini, serta pengarah ke masa yang akan datang.

Sejarah merupakan salah satu jembatan antara generasi tua dan generasi muda. Oleh karena itu, pengajaran sejarah mempunyai dua fungsi penting, yaitu menyampaikan nilai-nilai dalam rangka sosialisasi kepada peserta didik menyangkut masalah seleksi nilai-nilai yang akan disampaikan dan pengetahuan untuk latihan berpikir yang mampu membawa peserta didik memahami lingkungan secara rasional (Taufik Abdullah, 1995: 5). 
Setiap orang yang mempelajari sejarah dengan tekun akan menemukan garis yang berkesinambungan dalam perjalanan sejarah suatu masyarakat dan bangsa. Melalui pengajaram sejarah peserta didik akan menemukan pula betapa setiap peristiwa bahwa setiap peristiwa sejarah selalu berkaitan dengan peristiwa sejarah lainnya pada kurun waktu tertentu, yaitu antara peristiwa lokal, nasional, regional, dan internasional. Setiap peristiwa sejarah tidak berdimensi tungga, melainkan merupakan hasil interaksi dari berbagai kekuatan atau faktor-faktor sosial, politik, ekonomi, budaya, dan geografis.

Sejarah sebagai bidang pengetahuan yang memuat berbagai peristiwa masa lampau dapat menjadi sumber pelajaran mengenai berbagai peristiwa yang mencerminkan penerapan berbagai nilai seperti tampak dalam tekad, tindakan, dan perjuangan para pendahulu banghsa dalam berbagai kurun sejarah. Melalui pengajaran sejarah peserta didik diajak berkelana ke masa lampau untuk dapat memperoleh inspirasi dan imajinasi bagaimana para pelaku sejarah menjalani kehidupannya. Kesinambungan berbagai peristiwa sejarah mengandung nilai-nilai penting bagi pewarisan dan internalisasi kepada peserta didik.

Pengembangan pengajaran sejarah agar lebih fungsional dan terintegrasi dengan berbagai bidang kehidupan lainnya memerlukan perhatian terhadap berbagai bidang. Menurut Soedjiarto (1998), dalam rangka pengembangan nilai-nilai melalui pengajaran sejarah setidak- nya melalui tiga tahap, yaitu: pertama, tahap pengenalan dan pemahaman, yaitu pada saat seseorang mulai tertarik, memahami dan menghargai pentingnya suatu nilai bagi dirinya Sebagai pribadi dan anggota masyarakat, bangsa, dan negara. Kedua, tahap penerimaan, yaitu tahap pada seorang peserta didik mulai meyakini suatu nilai dan menjadikannya sebagai acuan dalam tindakan dan perbuatannya. Ketiga, tahap pengintegrasian, yaitu tahap pada saat peserta didik memasukkan suatu nilai dalam keseluruhan sistem nilai yang dianutnya. Pada tahap ini peserta didik telah dewasa memiliki kepribadian yang utuh, sikap yang konsisten dalam pendirian, dan sikap yang pantang menyerah dalam membela suatu nilai. Pada saat ini nilai yang diterimanya telah menjadi bagian dari kata hati dan kepribadiannya (Soedjiarto, 1998: 31).

Ketiga tahapan tersebut memerlukan pendekatan dan metode pembelajaran yang memungkinkan terjadinya internalisasi nilai-nilai.

Pada tahap pertama, pembelajaran yang ditempuh pada hakikatnya masih bersifat kognitif. Peserta didik akan berkenalan dengan nilai yang akan diinternalisasikan melalu proses belajar kognitif. Pendekatan dan metode proses informasi diperlukan, namun perlu disajikan dalam konteks berlakunya nilai-nilai tersebut. Pada tahap ini, peserta didik akan memperoleh gambaran tentang suatu nilai dalam konteksnya. Peserta didik akan memperoleh gambaran tentang Peranan diterapkannya suatu nilai dan pada saat yang sama mengandai- 
kan nilai tersebut tidak diterapkan oleh pelaku sejarah.

Peserta didik diajak mengenali nilai-nilai dengan kemampuan kognitifnya. Meski demikian, karena yang dipelajari adalah masalah kepentingan kehidupan manusia dalam hubungannya dengan sesama dan sebagai suatu bangsa, maka dengan sendirinya dimensi afektif akan mulai tersentuh. Berbagai metode yang dapat diterapkan untuk kepentingan tersebut adalah: mengajak atau menugaskan peserta didik menelaah peristiwa sejarah yang mengandung nilai yang sejajar ataupun yang kontradiktif; dialog tentang suatu nilai pada periode atau peristiwa sejarah tertentu; menugaskan untuk menuliskan kembali pengetahuannya tentang suatu nilai dengan bahasa mereka sendiri; dan curah pendapat dalam diskusi terbuka yang terpimpin dan diikuti oleh seluruh kelas, baik melalui kelompok besar maupun kecil untuk mempertajam pemahaman tentang arti suatu nilai (Soedjiarto, 1998: 35).

Pendekatan pembelajaran pada tahap penerimaan dapat dilakukan melalui: 1) menciptakan situasi kehidupan sosial yang menghubungkan peserta didik dengan lingkungan sosialnya dan memberikan kesempatan memilih serta merasakan akibat dari pilihannya tersebut; 2) memberi kesempatan untuk merenungkan dan memikirkan berbagai konsekuensi dari diterima dan tidaknya suatu nilai dalam kehidupan masyarakat; 3) memberi kesempatan untuk merasakan manfaat dari diterimanya suatu nilai dalam kehidupan bersama; 4) mendorong peserta didik melalui penghargaan dan pujian untuk menerapkan suatu nilai, dan 5) memberi kesempatan untuk mengulangi tindakan yang sesuai dengan nilai yang diterimanya (Soedjiarto, 1998: 36).

Pendekatan pembelajaran pada tahap pengintegrasian menjadikan nilai yang diterima sebagai bagian dari sistem kepribadiannya. Nilai-nilai yang diterima bukan suatu mozaik, melainkan merupakan suatu sistem yang dalam langkah dan tindakannya secara serasi dan seimbang menjadi kerangka acuan perbuatannya. Hakikat dari proses integrasi dalam suatu sistem nilai yang utuh, seimbang dan serasi, maka pendekatan dan metodenya pun sejajar dengan tahap sebelumnya. Situasi pendidikan dan sistem sosial yang dikembangkan di sebuah lembaga pendidikan akan lebih utuh, yaitu memahami berbagai nilai yang secara utuh menjadi sistem nilai pada diri peserta didik (Soedjiarto, 1998: 38).

Pemilihan metode pengajaran sejarah yang tepat menjadi penting dalam tahapan-tahapan tersebut di atas. Metode yang baik adalah yang mampu merangsang dan mengajak peserta didik untuk belajar. Dalam konteks pengajaran sejarah, agar pengajaran sejarah tidak menjadi bahan hafalan, maka dperlukan metode yang berorientasi pada pemecahan masalah. Peserta didik dirangsang untuk berpikir secara kritis, bahkan jika memungkinkan diberi kesempatan untuk melakukan pengembaraan intelektual melalui penjelajahan berbagai peristiwa sejarah. 


\section{B. Kemah Kerja Sejarah}

Kemah kerja sejarah mirip menemukan sendiri konsep-konsep atau nilai-nilai di balik obyek sejarah. Hanya saja, metode ini mengharapkan ditemukan data yang lebih intensif dan menyeluruh tentang peristiwa dibalik obyek sejarah. Kegiatan ini dilakukan di suatu tempat tertentu dan berlangsung beberapa hari. Karena di lokasi bersejarah itu biasanya tidak tersedia akomodasi, maka peserta dapat tinggal di kemahkemah, tidak ubahnya dengan kegiatan suatu tim ahli sejarah atau purbakala yang tinggal di lapangan beberapa lama waktunya.

Selama pelaksanaan perkemahan, peserta didik selain melakukan penelitian sesuai dengan yang direncanakan, juga mengadakan acaraacara selingan agar suasana tidak membosankan, seperti atraksi kesenian, lomba olah raga, dan lainlainnya (Widja, 1988 dan 2002 ).

Dengan demikian unsur-unsur yang harus diperhatikan dalam menerapkan metode ini adalah :

1. Kegiatan lebih bersifat informal (tidak terlalu diikat oleh disiplin yang kaku)

2. Menekankan Unsur kerelaan pada peserta, yang berarti sejak awal perlu ditanamkan unsur ketulusan dalam keikutsertaannnya.

3. Mengembangkan suasana rekreasi dalam keseluruhan kegiatan dan sekaligus memberi kesegaran sebagai selingan dari kegiatan-kegiatan di kelas yang kadang-kadang membosankan.
4. Mengandung ilustratif, dalam arti memantapkankan pengetahuan yang diberikan di kelas dengan gambaran nyata dari obyek yang diamati.

Menekankan penghayatan sejarah agar mendapatkan refleksi, inspirasi, dan edukasi.

\section{Pembelajaran Aktif, Inovatif, Kreatif, Efektif, dan Menye- nangkan}

\section{Pembelajaran Aktif}

Secara harfiah active artinya: "in the habit of doing things, energetic" (Hornby, 1994:12), artinya terbiasa berbuat segala hal dengan menggunakan segala daya. Pembelajaran yang aktif berarti pembelajaran yang memerlukan keaktifan semua siswa dan guru secara fisik, mental, emosional, bahkan moral dan spiritual.

Pendidik harus menciptakan suasana sedemikian rupa sehingga siswa aktif bertanya, membangun gagasan, dan melakukan kegiatan yang dapat memberikan pengalaman langsung, sehingga belajar merupakan proses aktif peserta didik dalam membangun pengetahuannya sendiri. Dengan demikian, siswa didorong untuk bertanggung jawab terhaap proses belajarnya sendiri.

Menurut Taslimuharrom (2008) sebuah proses belajar dikatakan aktif (active learning) apabila mengandung:

1) Keterlekatan pada tugas (Commitment)

Dalam hal ini, materi, metode, dan strategi pembelajaran hendaknya bermanfaat bagi siswa (meaningful), sesuai deng- 
an kebutuhan siswa (relevant), dan bersifat/memiliki keterkaitan dengan kepentingan pribadi (personal);

2) Tanggung jawab (Responsibility)

Dalam hal ini, sebuah proses belajar perlu memberikan wewenang kepada siswa untuk berpikir kritis secara bertanggung jawab, sedangkan guru lebih banyak mendengar dan menghormati ide-ide siswa, serta memberikan pilihan dan peluang kepada siswa untuk mengambil keputusan sendiri.

3) Motivasi (Motivation)

Proses belajar hendaknya lebih mengembangkan motivasi intrinsic siswa. Motivasi intrinsik adalah hal dan keadaan yang berasal dari dalam diri siswa sendiri yang dapat mendorongnya melakukan tindakan belajar. Dalam perspektif psikologi kognitif, motivasi yang lebih signifikan bagi siswa adalah motivasi intrinsik (bukan ekstrinsik) karena lebih murni dan langgeng serta tidak bergantung pada dorongan atau pengaruh orang lain. Dorongan mencapai prestasi dan memiliki pengetahuan dan keterampilan untuk masa depan, umpamanya, memberi pengaruh lebih kuat dan relatif lebih langgeng dibandingkan dengan dorongan hadiah atau dorongan keharusan dari orangtua dan guru. Motivasi belajar siswa akan meningkat apabila ditunjang oleh pendekatan yang lebih berpusat pada siswa (student centered learning).

\section{Pembelajaran Inovatif}

McLeod (1989) mengartikan inovasi sebagai: "something newly introduced such as method or device".

Berdasarkan takrif ini, segala aspek (metode, bahan, perangkat dan sebagainya) dipandang baru atau bersifat inovatif apabila metode dan sebagainya itu berbeda atau belum dilaksanakan oleh seorang guru meskipun semua itu bukan barang baru bagi guru lain (Dalam Muhibbin Syah \& Rahayu Kariadinata, 2009: $35)$.

Pembelajaran inovatif dapat menyeimbangkan fungsi otak kiri dan kanan apabila dilakukan dengan cara mengintegrasikan media/alat bantu terutama yang berbasis teknologi baru/maju ke dalam proses pembelajaran tersebut sehingga, terjadi proses renovasi mental, di antaranya membangun rasa pecaya diri siswa (Eric Jensen, 2007: 36-37). Penggunaan bahan pelajaran, software multimedia, dan microsoft power point merupakan salah satu alternatif inovasi pembelajaran berbasis teknologi informasi. Menurut Gani (2009: 5), teknologi informasi dalam kaitannya dengan pendidikan memiliki peran:

1. Behavioral: mengatur berbagai jenis media (teks, audio, video) dan membuatnya sebagai sebuah program pembelajaran.

2. Konstruktivis: memfasilitasi komunikasi kolaboratif antara siswa, instruktur dan tenaga ahli.

3. Proses informasi: membantu siswa mengatur informasi baru, menghubungkannya dengan pengetahuan dan menyimpannya ke dalam memori. 
Untuk menciptakan inovasi hendaknya mampu memahami pembelajaran, guru diharapkan dapat peserta didik, sehingga kita dapat menjadi motivator bagi peserta menciptakan inovasi pembelajaran didiknya. MenurutGagne (1975) ada empat fungsi yang harus dilakukan guru kaitannya sebagai motivator (Udin Syaefudin, 2009: 254).

Pertama, arousal function atau membangkitkan dorongan siswa untuk belajar. Kedua, expectancy function yaitu menjelaskan secara konkrit kepada siswa apa yang dapat dilakukan pada akhir pengajaran. Ketiga, incentive function, guru memberikan ganjaran untuk prestasi yang dicapai dalam rangka merangsang pencapaian prestasi berikutnya. Keempat, disciplinary function bahwa guru membantu keteraturan tingkah laku siswa. Keempat fungsi ini sebaiknya diperankan dengan tepat oleh guru dalam sebuah pembelajaran, karena pembelajaran merupakan suatu interaksi yang bersifat kompleks dan timbalbalik antara siswa dengan guru maupun siswa dengan siswa. Hendaknya siswa diberi kesempatan yang memadai untuk ikut ambil bagian dan diperlakukan secara tepat dalam pembelajaran.

Dengan inovasi pembelajaran, maka guru sebaiknya menciptakan suasana belajar yang menyenangkan (funny), menggairahkan (horee), dinamis (mobile), penuh semangat (ekspresif), dan penuh tantangan (chalange). Contoh inovasi sederhana yaitu membuka dan menutup pelajaran dengan nyanyian, membuat materi pelajaran menjadi syair lagu untuk mempermudah menghafal dan mengingat yang didukung dengan media. Oleh karena itu, sebagai guru

yang tepat dan sesuai dengan

kebutuhan dan perkembangan zaman untuk meningkatkan kemampuan kognitif, afektif, dan psikomotor peserta didik.

Pembelajaran yang inovatif akan mendorong peserta didik aktif dan kreatif, serta menciptakan suasana pembelajaaran yang menyenangkan. Pembelajaran yang menyenangkan perlu dipahami secara luas, bukan hanya berarti selalu diselingi dengan lelucon, banyak bernyanyi atau tepuk tangan yang meriah.

Pembelajaran yang menyenangkan adalah pembelajaran yang dapat dinikmati siswa. Siswa merasa nyaman, aman dan mengasyikkan. Perasaan yang mengasyikkan mengandung unsur inner motivation, yaitu dorongan keingintahuan yang disertai upaya mencari tahu sesuatu.

Selain itu pembelajaran juga perlu memberikan tantangan kepada siswa untuk berpikir, mencoba dan belajar lebih lanjut, penuh dengan percaya diri dan mandiri untuk mengembangkan potensi diri secara optimal. Dengan demikian, diharapkan kelak siswa menjadi manusia yang berkarakter penuh percaya diri, menjadi dirinya sendiri dan mempunyai kemampuan yang kompetitif (berdaya saing).

Menurut Muhibbin Syah \& Rahayu Kariadinata ciri-ciri pokok pembelajaran yang menyenangkan sebagai berikut.

1. Adanya lingkungan yang rileks, menyenangkan, tidak membuat tegang (stress), aman, menarik, 
dan tidak membuat siswa ragu melakukan sesuatu meskipun keliru untuk mencapai keberhasilan yang tinggi;

2. Terjaminnya ketersediaan materi pelajaran dan metode yang relevan;

3. Terlibatnya semua indera dan aktivitas otak kiri dan kanan;

4. Adanya situasi belajar yang menantangbagi peserta didik untuk berpikir jauh ke depan dan mengeksplorasi materi yang sedang dipelajari;

5. Adanya situasi belajar emosional yang positif ketika para siswa belajar bersama, dan ketika ada humor, dorongan semangat, waktu istirahat, dan dukungan yang antusias (Dalam Muhibbin Syah \& Rahayu Kariadinata, 2009: 35).

\section{Pembelajaran Kreatif}

Kreatif berarti menggunakan hasil ciptaan/kreasi baru atau yang berbeda dengan sebelumnya. Pembelajaran yang kreatif mengandung makna tidak sekedar melak-sanakan dan menerapkan kurikulum. Kurikulum memang merupakan dokumen dan rencana baku, namun tetap perlu dikritisi dan dikembang-kan secara kreatif. Dengan demikian, ada kreativitas pengembangan kompetensi dan kreativitas dalam pelaksanaan pembelajaran di kelas termasuk pemanfaatan lingkungan sebagai sumber bahan dan sarana untuk belajar.

Pembelajaran kreatif juga dimaksudkan agar guru menciptakan kegiatan Belajar yang beragam sehingga memenuhi berbagai tingkat kemampuan siswa dan tipe serta gaya belajar siswa. Di satu sisi pendidik bertindak kreatif mengembangkan kegiatan pembelajaran yang beragam dan membuat alat bantu belajar yang berguna meskipun sederhana. Di sisi lain, siswa pun kreatif dalam hal merancang/membuat sesuatu dan menulis/mengarang (CDalam Muhibbin Syah \& Rahayu Kariadinata, 2009: 32).

\section{Pembelajaran Efektif}

Pembelajaran dapat dikatakan efektif (berhasil guna) jika mencapai sasaran atau minimal mencapai kompetensi dasar yang telah ditetapkan. Di samping itu, yang juga penting adalah banyaknya pengalaman dan hal baru yang didapat siswa. Guru pun diharapkan memeroleh pengalaman baru sebagai hasil interaksi dua arah dengan siswanya. Untuk mengetahui keefektifan sebuah proses pembelajaran, maka pada setiap akhir pembelajaran perlu dilakukan evaluasi. Evaluasi yang dimaksud di sini bukan sekedar tes untuk siswa, tetapi semacam refleksi, perenungan yang dilakukan oleh guru dan siswa, serta didukung oleh data catatan guru. Hal ini sejalan dengan kebijakan penilian berbasis kelas atau penilaian authentic yang lebih menekan kan pada penilaian proses selain penilaian hasil belajar (Warta MBS UNICEF : 2006).

Guru menjadi pengajar yang efektif karena menguasai materi yang diajarkan; mengajar dan mengarahkan dengan memberi contoh; menghargai siswa dan memotivasi siswa; memahami tujuan pembelajaran; mengajarkan keterampilan pe- 
mecahan masalah; menggunakan metode yang bervariasi; mengembangkan pengetahuan pribadi dengan banyak membaca; mengajarkan cara mempelajari sesuatu; melaksanakan penilian yang tepat dan benar. Di sisi lain, siswa menjadi pembelajar yang efektif dalam arti menguasai pengetahuan dan keterampilan atau kompetensi yang diperlukan; mendapat pengalaman baru yang berharga.

\section{Pembelajaran Menyenangkan}

Pembelajaran yang menyenangkan (joyful) perlu dipahami secara luas, bukan hanya berarti selalu diselingi dengan lelucon, banyak bernyanyi atau tepuk tangan yang meriah. Pembelajaran yang menyenangkan adalah pembelajaran yang dapat dinikmati siswa. Siswa merasa nyaman, aman dan asyik. Perasaan yang mengasyikkan mengandung unsur inner motivation, yaitu dorongan keingintahuan yang disertai upaya mencari tahu sesuatu.

Selain itu pembelajaran perlu memberikan tantangan kepada siswa untuk berpikir, mencoba dan belajar lebih lanjut, penuh dengan percaya diri dan mandiri untuk mengembangkan potensi diri secara optimal. Dengan demikian, diharapkan kelak siswa menjadi manusia yang berkarakter penuh percaya diri, menjadi dirinya sendiri dan mempunyai kemampuan yang kompetitif (berdaya saing).

Adapun ciri-ciri pokok pembelajaran yang menyenangkan, ialah: adanya lingkungan yang rileks, menyenangkan, tidak membuat tegang (stress), aman, menarik, dan tidak membuat siswa ragu melakukan sesuatu meskipun keliru untuk mencapai keberhasilan yang tinggi; terjaminnya ketersediaan materi pelajaran dan metode yang relevan; terlibatnya semua indera dan aktivitas otak kiri dan kanan; adanya situasi belajar yang menantang (challenging) bagi peserta didik untuk berpikir jauh ke depan dan meng-eksplorasi materi yang sedang dipelajari; adanya situasi belajar emosional yang positif ketika para siswa belajar bersama, dan ketika ada humor, dorongan semangat, waktu istirahat, dan dukungan yang enthusiast.

Dalam pembelajaran yang menyenangkan guru tidak membuat siswa: takut salah dan dihukum; takut ditertawakan teman-teman; takut dianggap sepele oleh guru atau teman. Di sisi lain, pembelajaran yang menyenangkan dapat membuat siswa: berani bertanya; berani mencoba/berbuat; berani mengemukakan pendapat/gagasan; berani mempertanyakan gagasan orang lain.

Muhibbin Syah \& Rahayu Kariadinata merumuskan pembelajaran Pembelajaran Aktif, Inovatif, Kreatif, Efektif, dan Menyenangkan disingkat PAIKEM, yaitu pendekatan mengajar yang digunakan bersama metode tertentu dan pelbagai media pengajaran yang disertai penataan lingkungan sedemikian rupa agar proses pembelajaran menjadi aktif, inovatif, kreatif, efektif, dan menyenangkan. Di antara metode-metode yang dapat digunakan untuk mengimplementasikan PAIKEM, ialah: 1) metode ceramah plus, 2) metode diskusi; 3) metode demonstrasi; 4) metode role-play; dan 5) metode 
simulasi (Muhibbin Syah \& Rahayu Kariadinata, 2009: 1).

Cara melaksanakan PAIKEM mencakup berbagai kegiatan yang terjadi selama proses pembelajaran. Pada saat yang sama, kemampuan yang semestinya dikuasai guru untuk menciptakan keadaan sebaik-baiknya harus ditunjukkan.

\section{Metode Penelitian}

Penelitian Ini termasuk jenis penelitian deskriptif kualitatif. Penelitian dilakukan di Program Studi Pendidikan Sejarah IKIP PGRI MADIUN yang selama ini telah melaksanakan kemah kerja sejarah sebagai model pembelajaran. Data diperoleh dari sumber primer dan sekunder. Data primer yang berupa keterangan atau fakta di lokasi penelitian diperoleh dari informan, dan peristiwa atau aktivitas yang terkait dengan topik penelitian. Data sekunder berupa dokumen dan arsip tentang yang relevan dengan topik penelitian.

Pengumpulan data primer dilakukan dengan teknik wawancara mendalam dan observasi langsung. Wawancara dilakukan dengan Ketua Program Studi, para dosen, dan mahasiswa Program Studi Pendidikan Sejarah IKIP PGRI MADIUN. Observasi langsung dilakukan terhadap tempattempat atau lokasi diterapkannya kemah kerja sejarah. Data sekunder tentang objek penelitian diperoleh dengan mengumpulkan dokumen dan arsip yang ditemukan di lokasi penelitian.

Sampel informan dipilih secara selektif dan dilakukan secara mengalir dengan penyesuaian berkelanjutan sehingga semakin banyak narasumber semakin dipusatkan pada fokus studi. Pemilihan sampel berakhir jika telah terjadi perulangan. Pemilihan informan dapat berkembang sesuai dengan kebutuhan dan kemantapan peneliti dalam memperoleh data. Informan dipilih berdasarkan pengetahuan dan keterlibatan informan terkait dengan tema penelitian.

Validasi data dilakukan melalui teknik triangulasi sumber, yaitu dengan cara membandingkan data dari satu sumber data yang satu dengan sumber data yang lain, triangulasi teknik, yaitu membandingkan data dari satu teknik pengumpulan data dengan teknik yang lain, dan triangulasi peneliti, yaitu membandingkan data yang diperoleh anggota tim peneliti dengan anggota peneliti yang lain.

Analisis data dilakukan dengan metode analisis data kualitatif. Analisis data ditujukan pada data-data yang sifatnya kualitas dan sifat yang nyata diterapkan di lokasi penelitian. Ada dua cara yang digunakan dalam penelitian ini, yaitu analisis isi dan analisis interaktif. Untuk data dokumen dan arsip digunakan analisis isi, sedangkan untuk data hasil wawancara dan observasi digunakan analisis interaktif, seperti dikemukakan Milles dan Huberman (1996). Ada tiga komponen analisis yaitu: reduksi data sajian data dan penarikan kesimpulan. Aktivitas ketiga komponen dilakukan dalam bentuk interaktif dengan proses pengumpulan data 
sebagai suatu proses siklus. Peneliti hanya bergerak diantara tiga komponen analisis tersebut sesudah pengumpulan data selesai pada setiap unitnya dengan meman- faatkan waktu yang masih tersisa dalam penelitian ini. Untuk lebih jelasnya proses analisis interaktif dapat digambarkan dalam skema sebagai berikut.

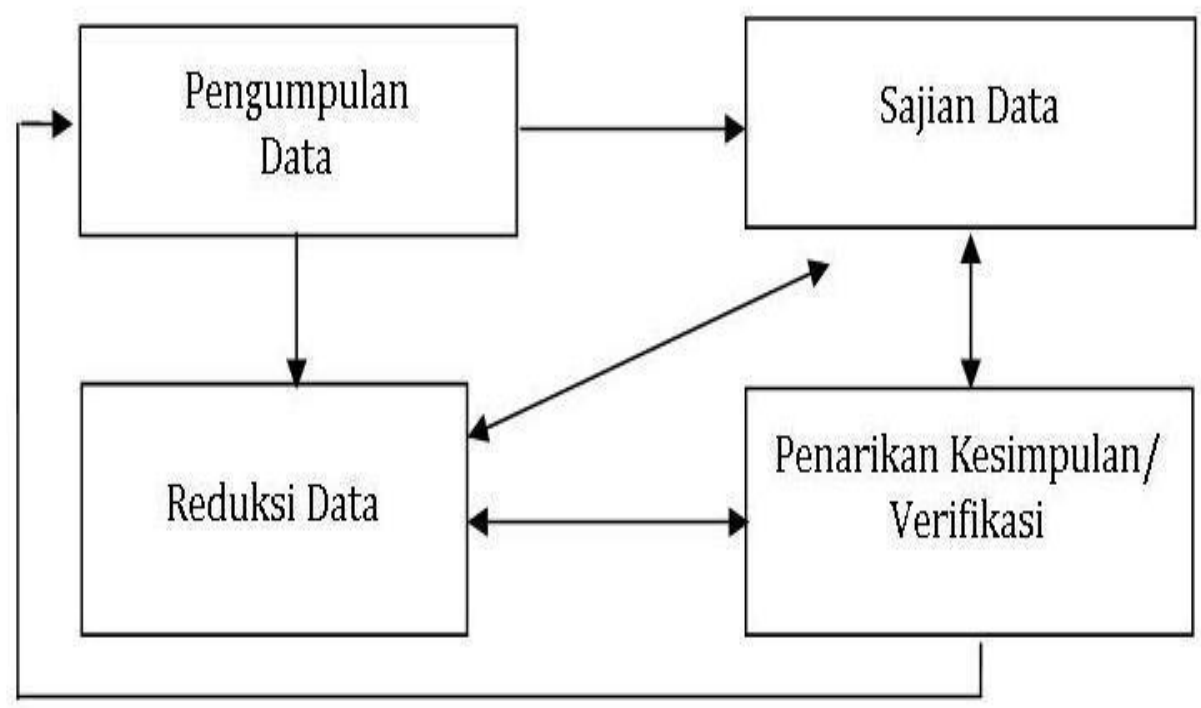

\section{Bagan 1. Analisis Data Interaktif}

Data mentah yang terkumpul di lokasi penelitan direduksi, disusun lebih sistematis, dipilih pokok yang penting, difokuskan dan dicari tema dan polanya. Selanjutnya dilakukan reduksi data, yaitu pemilihan, pemusatan perhatian pada penyederhanaan, pengabstrakan, dan transformasi data kasar yang muncul dari catatan-catatan tertulis di lapangan. Sistematisasi data dilakukan dengan membuat sajian data yang berupa tabel, jaringan, atau bagan. Dari sistematisasi data tersebut akan ditemukan pokok-pokok temuan yang penting, tema dan pola yang secara konsisten diterapkan di lokasi penelitian. Temuan-temuan tersebut dijadikan acuan menarik kesimpulan. Luaran penelitian ini berupa rancangan konseptual kemah sejarah sebagai metode pembelajaran sejarah, kendala-kendala dan cara pemecahannya serta kelebihan dan kelemahannya. Temuan ini diharapkan dapat memberi sumbangan bagi pengembangan keilmuan pendidikan sejarah dan menjadi bahan masukan bagi para dosen pendidikan sejarah, lembaga penyelenggara pendidikan 
sejarah, dan guru sejarah dalam memilih dan menerapkan metode pembelajaran yang aktif, inovatif, kreatif, efektif dan menyenangkan.

\section{Hasil Penelitian dan Pembahasan}

\section{A. Deskripsi Objek}

\section{Sejarah}

Sejarah Program Studi Pendi-

dikan Sejarah Fakultas Pendidikan Ilmu Pengetahuan Sosial IKIP PGRI

Madiun tidak lepas dari sejarah induknya, yaitu IKIP PGRI Madiun. IKIP PGRI Madiun dirintis mulai tahun 1971 oleh Yayasan Pembina Perguruan Tinggi Madiun (YAPPERTIMA) dengan nama IKIP DAERAH MADIUN. Dalam memperjuangkan IKIP DAERAH MADIUN ini pada tahun 1974 melakukan konfederasi dengan IKIP Sarmidi Mangun Sarkoro yang berpusat di Malang dan berganti nama IKIP Sarmidi Mangun Sarkoro di Madiun. Konfederasi ini belum pula memberikan status. Akhirnya pada tahun 1975 IKIP Sarmidi Mangun Sarkoro di Madiun ini oleh YAPPERTIMA diserahkan kepada Pimpinan Daerah PGRI VIII Jawa Timur untuk dibina, kemudian namanya berganti menjadi IKIP PGRI Jawa Timur di Madiun. Berkat perjuangan yang tidak kenal lelah, maka pada tahun 1975 berdasarkan Akte Notaris Anwar Nahayudi No. 44 tanggal 13 Nopember 1975 mengusulkan status. Setahun kemudian tepatnya 17 Mei 1976 mendapat status terdaftar dari Kopertis Wilayah VI No. 85/I/76.

IKIP PGRI Jawa Timur di Madiun dengan Surat Keputusan Menteri Pendidikan dan Kebudayaan tanggal 18 Pebruari 1985 diakui sebagai IKIP yang mandiri dengan nama IKIP PGRI Madiun, yang dibina oleh Yayasan Pembina Lembaga Pendidikan Perguruan Tinggi PGRI Kotamadya Madiun (YPLP PT PGRI Kotamadya Madiun). Yayasan ini didirikan dengan Akta Notaris R. N. Sinulingga, SH., tanggal 31 Mei 1985 No. 103 dan bertanggungjawab langsung kepada Yayasan Pembina Lembaga Pendidikan PGRI Pusat di Jakarta. Di dalam perkembangan selanjutnya kemandirian dan status terdaftar IKIP PGRI Madiun itu dikuatkan lagi dengan SK Mendikbud No. 0395/0/1986 tanggal 25 Mei 1986.

Dengan demikian Program Studi Pendidikan Sejarah IKIP PGRI Madiun secara yuridis formal didirikan oleh Yayasan PGRI Daerah VIII Jawa Timur dengan Akte Notaris Anwar Nahayudi No. 44 tanggal 13 Nopember 1975. Setahun kemudian tepatnya 17 Mei 1976 mendapat status terdaftar dari Kopertis Wilayah VI No. 85/I/76. Empat belas tahun kemudian statusnya naik menjadi diakui. Hal ini berdasarkan Keputusan Menteri Pendidikan dan Kebudayaan No. 0603/0/1990 tanggal 13 September 1990 .

Seiring dengan adanya perubahan yang fundamental dalam dunia pendidikan tinggi di Indonesia, terutama dalam mengaselarsi dan adaptasi terhadap perkembangan ilmu pengetahuan dan teknologi, serta perubahan ekspektasi masyarakat terhadap peranan perguruan tinggi dalam merintis masa depan bangsa dan negara, maka perguruan tinggi dituntut untuk mampu 
membuktikan mutu yang tinggi yang didukung oleh akuntabilitas yang baik. Oleh karena itu pemerintah dalam hal ini menteri Pendidikan dan kebudayaan mengadakan program akreditasi perguruan tinggi secara nasional yang dilaksanakan oleh Badan Akreditasi Nasional Perguruan Tinggi (BAN PT). Untuk itu Program Studi Pendidikan Sejarah mengajukan usulan untuk diakreditasi.

Akreditasi yang pertama dilaksanakan pada tahun 1997 dengan hasil Terakreditasi Peringkat Nilai C berdasarkan Surat Keputusan Badan Akreditasi Nasional Perguruan Tinggi Departemen Pendidikan dan Kebudayaan Nomor 002/BAN-PT/AkII/XII/1998. Mengingat masa berlaku akreditasi dengan nilai $\mathrm{C}$ tersebut tiga tahun, maka pada tahun 2001

Program Studi Pendidikan Sejarah mengusulkan ke BAN PT untuk reakreditasi dan hasil ada peningkatan yaitu Terakreditasi Peringkat Nilai B. Hal tersebut dituangkan dalam Surat Keputusan Badan Akreditasi Nasional Perguruan Tinggi Departemen Pendidikan Nasional Nomor : 004/BAN PT/Ak.V/S1/IV/2002 Tanggal 5 April 2002. Masa berlaku surat keputusan tersebut sampai dengan 4 April 2007. Dalam reakreditasi, Prodi Sejarah kembali mendapat nilai B. Tertuang dalam Surat Keputusan Badan Akreditasi Nasional Perguruan Tinggi Departemen Pendidikan Nasional Nomor: 010/BAN PT/Ak-X/S1/V/ 2007 Tanggal 19 Mei 2007, berlaku hingga 18 Mei 2012.

\section{Visi, Misi, dan Tujuan}

Visi Program Studi Pendidikan Sejarah IKIP PGRI MADIUN adalah mewujudkan program studi yang handal dalam mengembangkan sumber daya manusia di bidang kependidikan sejarah yang profesional dan memiliki kemampuan kompetetif dalam peningkatan kualitas hidup dan kehidupannya di tingkat regional.

Misinya adalah melaksanakan Tri Dharma Perguruan Tinggi dalam rangka menghasilkan lulusan yang profesional dan memiliki kemampuan kompetetif dalam pendidikan sejarah, serta mampu melaksanakan penelitian dan pengabdian kepada masyarakat.

Adapun tujuannya adalah menghasilkan sarjana Pendidikan Sejarah yang memiliki kualifikasi, kompetensi dan professional seperti yang dirumuskan pada tujuan IKIP PGRI Madiun dan memiliki kekhasan kemampuan pengetahuan dasar tentang sejarah secara komprehensif, mantap dan mendalam, sehingga dapat menerapkan dan mengembangkan bidang studi tersebut, serta menyesuaikan dengan berbagai situasi dan perubahan.

\section{Pendidikan dan Pengajaran}

a) Program Pendidikan

Program pendidikan yang diselenggarakan Program Studi Pendidikan Sejarah IKIP PGRI Madiun merupakan program gelar Sarjana Strata Satu (S-1). Gelar ini diperoleh dengan beban studi komulatif 150 SKS dan lama studi 0-14 semester.

b) Kurikulum

Untuk mencapai tujuannya, program studi mengembangkan kuri- 
kulum dengan berpedoman pada

prinsip-prinsip dasar sebagai berikut:

1) Kurikulum dikembangkan pada standar nasional pendidikan,

2) Berorientasi kepada tujuan pendidikan tenaga kependidikan,

3) Fokus pendidikan berlandasan prinsip penyatuan pengetahuan teori dan praktik,

4) Diversifikasi (keragaman) program disusun dengan memperhatikan kebutuhan guru dan tenaga kependidikan yang lain,

5) Sifat keterbukaan program yang memungkinkan kelanjutan atau kepindahan dari program satu ke program lain.

6) Didasarkan pada kriteria 10 sepenuth kependidikan dasar masing-masing. yaitu antara lain: menguasai landasan-landasan kependidikan, mengelola program belajar mengajar, mengelola kelas, menggunakan media, mengelola interaksi belajar mengajar, menilai prestasi siswa untuk kepentingan pengajaran, mengenal fungsi dan program layanan bimbingan dan penyuluhan di sekolah, mengenal dan menyelenggarakan administrasi sekolah, memahami prinsip-prinsip dan menafsirkan hasil-hasil penelitian pendidikan guna kepentingan pengajaran.

Selain itu juga didasarkan pada 3 kompetensi tambahan guru sejarah, yaitu : kualitas prima dalam masalah kemanusiaan, pengetahuan yang luas tentang kebudayaan, dan pengabdi perubahan dan kebenaran.

\section{Organisasi Kurikulum}

Kurikulum terdiri atas kurikulum inti $=40 \%-80 \%$ dari jumlah
SKS program sarjana dan 20\%-60\% untuk kurikulum institu-sional. Kurikulum inti terdiri atas kelompok matakuliah pengembangan kepribadian, kelompok matakuliah yang mencirikan tujuan pendidikan dalam bentuk penciri ilmu pengetahuan dan ketrampilan, keahlian berkarya, sikap berperilaku dalam berkarya dan cara berkehidupan bermasyarakat. Sedangkan kurikulum intitusional terdiri dari kurikulum institut dan kurikulum program studi.

Untuk kurikulum institusional institut penyusunannya dilakukan oleh institut dan institusional progam studi penyusunannya diserahkan

nya kepada program studi kompetensi Berdasarkan Surat Keputusan Mendiknas RI Nomor : 232/U/2000 setiap rumpun kompetensi dikelompokkan dalam kelompok-kelompok mata kuliah sebagai berikut :

a. Kelompok Mata Kuliah Pengembangan Kepribadian (MPK) meliputi matakuliah yang relevan dengan tujuan pengayaan wawasan, pendalaman intensitas pemahaman dan penghayatan (MPK inti dan MPK institusional).

b. Kelompok Mata Kuliah Keilmuan dan Ketrampilan (MKK), meliputi mata kuliah untuk memperkuat penguasaan dan memperluas wawasan kompetensi keilmuan atas dasar keunggulan kompetitif serta komparatif penyelenggaraan program studi yang bersangkutan.

c. Kelompok Mata Kuliah Keahlian Berkarya (MKB), meliputi matakuliah yang bertujuan untuk memperkuat penguasaan dan memperluas wawasan kompetensi 
keahlian dalam berkarya di masyarakat keunggulan komparatif sesuai kompetetif dengan program studi bersangkutan.

d. Kelompok Mata Kuliah Perilaku Berkarya (MPB), meliputi matakuliah yang bertujuan untuk memperkuat penguasan dan memperluas wawasan perilaku berkarya sesuai dengan ketentuan yang berlaku di masyarakat untuk setiap program studi.

e. Kelompok Mata Kuliah Berkehidupan Bermasyarakat (MBB), yang terdiri atas matakuliah yang relevan dengan upaya pe-

mahaman serta penguasaan ketentuan yang berlaku dalam berkehidupan dimasyarakat, baik secara nasional maupun global yang membatasi tindak kekaryaan seseorang sesuai dengan kompetensi keahliannya.

Pengelompokkan mata kuliah tersebut di atas dengan empat pilar pendidikan (The four pillars of education), yaitu learning to know, learning to do, learning to be dan learning to live together. Dalam pelaksanaan KBK tersebut proses pembelajaran mengikuti paradigma baru, karena perguruan tinggi bukan lagi merupakan sumber utama ilmu pengetahuan. Mahasiswa dapat memperoleh atau belajar dari berbagai sumber dan fungsi dosen sebagai fasilitator. Dengan demikian kurikulum inti suatu program studi yang disusun oleh perguruan tinggi sebagaimana Surat Kutusan Mendiknas RI Nomor 045/U/2002 harus bersifat:
1) Dasar untuk mencapai kompetensi lulusan.

2)Acuan baku minimal mutu penyelenggaraan program studi.

3) Berlaku secara nasional dan internasional.

4) Lentur dan akomodatif terhadap perubahan yang sangat cepat dimasa dating.

5) Kesepakatan bersama antara kalangan perguruan tinggi, masyarakat profesi dan pengguna lulusan.

Kurikulum Berbasis Kompetensi (KBK) yang dilaksanakan oleh IKIP PGRI Madiun tersebut terdiri dari kompetensi utama dan komptensi pendukung. Kompetensi utama merupakan pengetahuan, kemampuan dan sikap yang diperlukan untuk dapat melakukan tugas sebagai seorang profesional di bidangnya. Disebut utama karena jika seseorang lulusan yang tidak memiliki pengetahuan, kemampuan dan sikap yang dimaksud, maka lulusan ter-sebut tidak akan mampu melak-sanakan tugas sebagaimana seorang profesional. Sedangkan kompetensi pendukung merupakan seperangkat pengetahuan kemampuan dan sikap yang perlu dimilki seorang lulusan untuk mendukung pengembangan profesinya agar menjadi ahli di bidang yang lebih khusus agar dapat bekerja di dunia usaha atau berwirausaha.

Kompetensi yang telah ditetapkan tersebut selanjutnya dijabarkan ke dalam sub kompetensi dalam bentuk kemampuan-kemampuan rinci yang diberikan kepada mahasiswa untuk dikuasai sebagai persyaratan minimal kelulusan. Kemampuan tersebut dikelompokkan 
ke dalam 5 elemen kompetensi. Dari sub kompetensi tersebut maka dapat dijabarkan pada substansi kajian sesuai dengan kelompok mata kuliah dari 5 pilar tersebut. Dengan demikian matakuliah baru bukan didasarkan pada pohon keilmuan tetapi pada substansi-substansi bahan kajian. Sedangkan penyebaran matakuliah dan pengelompokannya sesuai dengan sifat dan karakteristik program studi masing-masing.

\section{B. Rancangan Model Kemeja}

Model pembelajaran merupakan suatu rencana atau pola yang digunakan dalam menyusun kurikulum, mengatur materi pembelajaran, dan memberi petunjuk kepada pengajar di dalam kelas dalam setting pengajaran. Untuk menetapkan model pembelajaran yang tepat, merupakan suatu pekerjaan yang tidak mudah, karena memerlukan pemahaman yang mendalam mengenai materi yang akan diberikan dan model pembelajaran yang dikuasai.

Mengembangkan suatu model pembelajaran harus juga disesuaikan dengan realitas yang ada dan situasi kelas yang akan dihasilkan dari proses kerjasama yang dilakukan antara dosen/guru dan peserta didik. Meskipun dalam menentukan model mengajar yang cocok itu tidak mudah, tetapi dosen harus memiliki asumsi, bahwa hanya ada model mengajar yang sesuai dengan model belajar. Apabila dosen mengharapkan peserta mahasiswa menjadi produktif, maka dosen harus membiarkannya dia berkembang sesuai dengan gayanya masing-masing. berperan sebagai fasilitator dalam proses belajar peserta didik.

Model pembelajaran yang textbook, ceramah, mencatat, dan menghafal jelas akan membuat pelajaran sejarah ini ditinggalkan begitu saja. Pendidik seharusnya mampu menggiring anak untuk berpartisipasi secara penuh dalam setiap kegiatan belajar. Metode yang mengajak peserta didik memasuki apa yang dinamakan lingkungan sosial dan budaya belum banyak diperkenalkan. Sejauh ini sangat jarang dosen/guru mempergunakan kesempatan untuk berupaya mengarahkan peserta didik mencari sendiri informasi apa saja sehingga hal itu dapat membangun pengetahuan sejarah secara mandiri (konstruktivisme). Dalam konstruktivisme, pendidik tidak dengan sendirinya memindahkan penge-tahuan kepada peserta didik dalam bentuk yang serba sempurna. Peserta didik harus membangun suatu pengetahuan berdasarkan pengalamannya masingmasing. Pembelajaran adalah hasil usaha peserta didik itu sendiri. Hal ini terkait dengan aktivitas mental peserta didik sebagai bahan mentah bagi proses renungan dan pengabstrakan. Pikiran peserta didik tidak akan menghadapi kenyataan dalam bentuk yang terasing dalam lingkungannya sendiri. Realita yang dihadapi peserta didik adalah realita yang mereka bina sendiri. Untuk itu, guru harus memperkirakan struktur kognitif yang ada pada mereka. Jika pengetahuan baru sudah mampu diserap dan dijadikan pegangan mereka, baru guru dapat memberikan 
informasi pengetahuan yang melimpah (Utomo, 2007: 4)

Upaya pembentukan kemampuan menemukan sesuatu secara mandiri informasi yang akan dibentuk menjadi pengetahuan tersebut (Inquiry) salah satu upayanya adalah model kemah kerja sejarah, disingkat Kemeja. Model ini pada dasamya mirip dengan model yang kedua di atas, yaitu menekankan aktivitas serta kreativitas murid untuk mencari atau menemukan data kesejarahan dari suatu obyek sejarah. Hanya saja model ini mengharapan peserta didik dapat menemukan data yang lebih intensif dan bersifat menyeluruh yang mencerminkan peristiwa yang melatarbelakangi obyek tersebut. Untuk itu pelaksanaan kegiatan biasanya dilakukan di suatu tempat tertentu saja dan berlangsung beberapa hari. Karena di lokasi bersejarah itu biasanya tidak tersedia akomodasi maka muridmurid bisa tinggal di kemah-kemah, jadi tak ubahnya dengan suatu kegiatan perkemahan pramuka, hanya sifat kegiatan yang berbeda. Ini bisa diperbandingkan juga dengan kegiatan suatu tim ahli sejarah atau ahli purbakala yang tinggal di lapangan beberapa lama, khusus untuk menggali data sebanyakbanyaknya dan suatu peninggalan sejarah yang belum banyak diungkapkan. Dengan cara seperti ini menjadilah peserta didik itu seakan-akan sebagal sejarawan-sejarawan. Di sini bukan saja sikap penghayatan sejarah yang bisa dikembangkan, tapi juga beberapa aspek keterampilan penting terutama bekerja dengan tanggung jawab sendiri.
Model ini hampir sama dengan lawatan sejarah, hanya saja dalam kemah kerja ini peserta didik berada di sebuah tempat yang menyerupai tenda atau home stay yang di dalam kegiatan tersebut ada beragam permainan, lomba, atraksi kesenian, sarasehan, dan sebagainya yang dapat memacu peserta didik mengenal lingkungan sosial budaya dan sejarah.

Model kemah kerja ini menjawab paradigma bahwa sejarah tidak hanya berkaitan dengan masa lalu saja. Kemah kerja justru mampu mengingatkan apa yang dapat kita hindarkan dan mana yang dapat kita pupuk terus sebagai sumber motivasi membangun kebersamaan. Dalam konteks sejarah, kebersamaan justru prioritas dibangun melalui komitmen dan tindakan nyata, seperti halnya dahulu ketika bangsa kita mengusir penjajah (Nurjanto, 2007: 5 \& Lestariningsih, 2007: 3).

Kemeja merupakan alternatif pembelajaran yang menarik dan tidak membosankan. Kemeja merupakan upaya menjadikan sejarah sebagai kata kerja. Sejarah sebagai praktik tentu akan lebih menyenangkan bagi peserta didik untuk belajar apalagi diimbangi dengan berwisata. Pendidik dapat mengajak peserta didik didik mengunjungi situs dan monumen sejarah. Untuk memperdalam pemahaman dan pemaknaan peserta Kemeja dapat berdialog dengan sejarawan, tokoh/pelaku sejarah dan narasumber sejarah lokal (Zuhdi, 2007: 4).

Sejarah bangsa dapat dilacak pada situs-situs, bangunan bersejarah, dan lingkungan masyarakat setempat. Masyarakat melalui sejarah 
lisan atau tradisi lisan masih menyimpan kenangan tentang para pejuang yang diasingkan atau yang ada di daerahnya. Dalam hal ini, tempat-tempat tersebut menjadi simpul-simpul yang menghubungkan sejarah antar daerah yang memberi sumbangan pada terbentuknya keindonesiaan. Oleh karena itu upaya penelusuran simpul tersebut dapat dilakukan melalui kemah budaya (Nurjanto, 2007: 5).

Obyek-obyek sejarah yang berdekatan dengan seting dilaksanakan kegiatan Kemeja semakin diharapkan mampu mendekatkan peserta didik atau peserta kemah pada realitas masa lalu yang sebenarnya. Mereka dapat bertanya langsung pada ahli yang mengetahui hal-ikhwal sebuah benda cagar budaya. Di selasela bertanya mereka dapat menikmati keindahan alam lingkungan dan merasakan prosesi napak tilas ke masa lalu melalui mekanisme yang menyehatkan.

Dengan cara tersebut peserta didik akan menemukan sebuah transformasi pengetahuan historis dan budaya dengan sendirinya. Rasa kehausan mereka akan informasi masa lalu memunculkan semangat pencarian tentang masa lalu yang di lingkungan setempat. Ketika proses itu berjalan maka dengan sendirinya akan memunculkan pula ego sosial budaya masing-masing. Ego ini akan berangsur hilang bila pada saat berdiskusi dan bertanya jawab yang ada dalam session tersebut dilaksanakan. Peserta yang berasal dengan latar belakang budaya dan sosial satu dengan yang lainnya akan merasa sama dan menyatu dalam status sosial mereka yang baru yaitu samasama sebagai peserta kemah budaya. Di sini mereka mulai menemukan arti persamaan dan persaudaraan. Apalagi dalam kegiatan Kemeja juga diimbangi dengan atraksi seni yang bermacam-macam semakin menambah semangat penghargaan dengan insan sesama.

Model Kemeja secara umum terdiri dari empat komponen kegiatan, yaitu persiapan, pelaksanaan, evaluasi dan refleksi, serta pelaporan (wawancara dengan Abraham Nurcahyo, 8 Maret 2012).

\section{Persiapan}

Dalam rangka pelaksanaan model kemeja, dosen bersama-sama dengan mahasiswa mengadakan persiapan pendahuluan yang cukup intensif sebelum terjun ke lapangan.

Persiapan itu meliputi misalnya penentuan suatu teknik studi yang dianggap cukup menarik untuk diselidiki lebih jauh yang berkaitan dengan suatu objek sejarah tertentu. Mahasiswa mengorganisir diri sebagai suatu grup studi dengan pembagian tugas yang jelas dan anggota kelompok masing-masing (kelompok besar kalau perlu bisa di pecah menjadi kelompok-kelompok kecil dengan tugas-tugas tertentu sesuai dengan kepentingan). Dengan sendirinya juga mahasiswa diharapkan menyusun rencana (design) penelitian yang berisi langkahlangkah kegiatan di lapangan, pengumpulan data sampai pada penyusunan laporannya). Dosen membantu mahasiswa menyiapkan bahan-bahan pengkajian pendahuluan, di samping mahasiswa sendiri 
dianjurkan untuk mencari sendiri bahan-bahan tersebut. Untuk melengkapi bahan-bahan acuan penelitian, kalau dianggap perlu, bisa diundang beberapa ahli sejarah atau ahii purbakala, terutama yang menyangkut informasi pendahuluan yang perlu dipegang oleb murid. Juga untuk memberi petunjuk-petunjuk praktis mengenai langkah-langkah yang perlu diambil untuk mengefektifkan kerja di lapangan. Sedangkan sesudah di lapangan, kalau ini menyangkut sejarah kontemporer, bisa diundang pelaku-pelaku sejarah untuk memberi ceramah tentang pengalamannya yang menyangkut peristiwa yang sedang diselidiki yang akan merupakan data yang sangat penting bagi studi sejarah yang sedang dilakukan.

Dengan sendirinya juga perlu disiapkan segala keperluan bagi suatu perkemahan, termasuk perbekalan/ logistiknya serta kemah-kemah secukupnya. Dengan persiapan yang demikian itu maka murid-murid diajak ke lapangan (ke tempat objek sejarah), dan selama di tempat itu melaksanakan kegiatan "penelitian sesuai dengan rincian jadwal yang sudah disusun sebelumnya. Tentu saja selama perkemahan itu bisa diadakan acara-acara selingan agar suasananya tidak terlalu membosankan seperti menyelenggaraan atraksi/ hiburan yang dilaksanakan oleb murid-murid sendiri. Di sini juga peranan guru terutama bersifat membimbing saja, karena hampir seluruh kegiatan diharapkan dilaksanakan oleh murid-murid sendiri.

\section{Pelaksanaan}

Pelaksanaan Kemeja terdiri dari tiga jenis kegiatan utama: klarifikasi dan eksplorasi objek, social mapping, diskusi analisis, pertunjukkan seni.

\section{a. Klarifikasi dan eksplorasi objek}

Kegiatan

ini merupakan kegiatan peserta kemeja untuk mengklarifikasi materi yang sudah diperoleh di kampus dengan realitas yang senyatanya. Realitas teoretis yang diperoleh di kampus diklarifikasi dengan realitas objektif yang ditemukan di lapangan. Klarifikasi disertai dengan eksplorasi peserta terhadap objek yang belum diperolah dari realitas teoretis di kampus.

Dengan begitu peserta diharapkan lebih mendalam pemahamannya terhadap objek. Kegiatan ini didampingi oleh dosen atau ahli berkompeten.

\section{b. Pemetaan Sosial (Social Map- ping)}

Pemetaan sosial (social mapping) merupakan proses penggambaran masyarakat yang sistematik serta melibatkan pengumpulan data dan informasi mengenai masyarakat termasuk di dalamnya profile dan masalah sosial yang ada pada masyarakat tersebut. Pemetaan sosial dapat dipandang sebagai salah satu pendekatan dalam Pengembangan Masyarakat yang oleh Twelvetrees (1991:1) didefinisikan sebagai proses memfasilitasi masyarakat untuk meningkatkan komunitas dengan melakukan aksi kolektif (Edi Suharto dalam http://www.policy. hu/suharto/modul a/makindo 18.ht m, diakses 3 April 2012. 
Sebagai sebuah pendekatan, pemetaan sosial sangat dipengaruhi oleh ilmu penelitian sosial dan geografi. Salah satu bentuk atau hasil akhir pemetaan sosial biasanya berupa suatu peta wilayah yang sudah diformat sedemikian rupa sehingga menghasilkan suatu image mengenai karakteristik masyarakat atau masalah sosial. Tidak ada aturan dan bahkan metoda tunggal yang secara sistematik dianggap paling unggul dalam melakukan pemetaan sosial. Prinsip utamanya adalah bahwa ia dapat mengumpulkan informasi sebanyak mungkin dalam suatu wilayah tertentu secara spesifik yang dapat digunakan sebagai bahan membuat suatu keputusan terbaik dalam proses fasilitasinya.

Kegiatan pemetaan sosial dalam Model Kemeja ini dilakukan per kelompok. Panduan pemetaannya sebagai berikut.

Focus A : Memahami karakteristik masyarakat Apa yang diketahui mengenai sejarah populasi sasaran pada masyarakat ini?

1. Berapa orang jumlah pendduduk dan bagaimana karakteristiknya?

2. Bagaimana orang-orang dalam populasi sasaran memandang kebutuhan-kebutuhannya?

3. Bagaimana orang-orang dalam populasi sasaran memandang masyarakat dan kepekaannya dalam merespon kebutuhankebutuhan mereka?

Focus B : Mengidentifikasi batasbatas masyarakat:
1. Bagaimanakah batas-batas wilayah geografis masyarakat setempat?

2. Dimana anggota-anggota masyarakat bertempat tinggal dalam batas wilayah geografisnya?

3. Apa hambatan fisik yang ada dalam masyarakat?

Fokus C: Menggambarkan

masalah-masalah sosial :

1. Apa permasalahan sosial utama di masyarakat?

2. Adakah sub-sub kelompok dari masyarakat yang mengalami permasalahan sosial utama?

3. Data apa yang tersedia mengenai permasalahan sosial yang teridentifikasi dan bagaimana data tersebut digunakan di dalam masyarakat?

4. Siapa yang mengumpulkan data, dan apakah ini merupakan proses yang berkelanjutan?

Fokus D: Memahami nilai-nilai dominan :

1. Apa nilai-nilai budaya, tradisi, atau keyakinan-keyakinan yang penting bagi masyarakat?

2. Apa nilai-nilai dominan yang mempengaruhi masyarakat?

3. Kelompok-kelompok dan individu-individu manakah yang menganut nilai-nilai tersebut dan siapa yang menentangnya?

4. Apa konflik-konflik nilai yang terjadi pada masyarakat?

Fokus E: Memahami lokasi-

lokasi kekuasaan :

1. Apa sumber-sumber utama pendanaan (baik lokal maupun dari luar masyarakat)?

2. Adakah pemimpin-pemimpin kuat dalam masyarakat yang mempengaruhi pelayanan yang dirancang bagi masyarakat? 
Fokus F: Menentukan ketersediaan sumber

1. Apa lembaga-lembaga dan kelompok-kelompok masyarakat yang ada pada saat ini yang dipandang sebagai pemberi pelayanan bagi populasi sasaran?

2. Apa sumber utama pendanaan pelayanan-pelayanan bagi populasi sasaran?

3. Apa sumber-sumber nonfinansial yang diperlukan dan tersedia? (Laporan Kemeja, 2009)

\section{c. Diskusi Analisis}

Kegiatan ini merupakan ajang untuk pertukaran ide, pemikiran, dan pengalaman para mahasiswa tentang berbagai tema (isu) menyangkut objek sejarah dan lingkungan sosial budaya di sekitar lokasi Kemeja. Diskusi diikuti seluruh peserta dan didampingi oleh para dosen. Diskusi diawali dengan presentasi kelompok mahasiswa. Bahan presentasi multimedia (Power Point) harus terlebih dahulu disampaikan pada panitia, tetapi pelaksanaannya akan dipandu oleh seorang mederator dari mahasiswa lain. Tema pokok diskusi analisis sebagai berikut.

Tema 1: Makna dan Perlakuan pada Warisan Sejarah dan Budaya Tema ini mengacu pada hal-hal berikut:

a. Deskripsi warisan sejarah dan budaya di lokasi Kemeja

b. Nilai-nilai yang terkandung di dalamnya (pada bentuk artistik, teknik pembuatan/penciptaan atau sejarah). Usahakan contohcontoh yang disampaikan sekongkret

berdasarkan pengalaman.

c. Urgensi nilai dari masa lampau pada warisan sejarah dan budaya di lokasi Kemeja untuk kehidupan sekarang atau masa mendatang yang kondisinya sangat berbeda dengan masa lalu.

d. Perlakuan yang seharusnya terhadap warisan sejarah dan budaya di lokasi Kemeja

e. Jika warisan sejarah dan budaya ini adalah aset peradaban bangsa, bagaimana memanfaatkannya untuk dunia pendidikan, peningkatan ekonomi pariwisata.

Tema 2: Preservasi dan Inovasi Warisan Sejarah dan Budaya

Tema ini mengangkat kontroversi antara upaya preservasi (pemeliharaan, pelestarian) dan inovasi (pembaruan, pengembangan). Jika preservasi untuk menjaga agar suatu peninggalan sejarah budaya tidak hilang, tidak berubah, maka inovasi adalah sebaliknya: untuk diubah, diolah, disesuaikan dengan kebutuhan. Pandangan umum yang sering terdengar adalah bahwa suatu peninggalan sejarah budaya harus diolah dan dikemas ulang, tetapi tidak mengubah atau menghilangkan nilai akarnya. Diskusi tema ini untuk menjawab pertanyaanpertanyaan: upaya konservasi dan preservasi yang sudah dilakukan (melalui pengamatan ataupun studi pustaka); hasilnya (bentuknya baru, penerimaan publik); argumen warisan sejarah dan budaya harus dipertahankan, cara dan peran 
masyarakat sekitar berdasarkan hasil pemetaan sosial.

Dosen mendampingi proses diskusi. Sesekali dosen diberi kesempatan untuk memberikan respon ataupun klarifikasi apabila jalannya diskusi melebar dan tidak merangsang munculnya jawabanjawaban yang berbobot (wawancara dengan Yudi Hartono, 10 Maret 2012).

\section{d. Pentas Seni}

Setiap kelompok menampilkan satu seni pertunjukkan, bisa berupa penampilan drama dengan tema sejarah dan tari-tarian daerah.

Melalui kegiatan ini peserta diharapkan dapat mengenali potensi dan mengolah tubuh (gerak) dan suara sebagai media bagi seorang calon guru untuk tampil di depan kelas. Pelbagai tema cerita sejarah properti yang ada menjadi bahan eksplorasi untuk mewujudkan makna atau kekuatan penampilan. Interaksi dengan audien atau penonton menjadi penting karena menyangkut hubungan sosial dan lingkungan yang penting bagi calon guru.

Demikian pula dengan tari yang tertuju pada pendayaan tubuh pada ruang, waktu, dan enerji. Kelenturan, keterampilan, dan kepekaan tubuh dikembangkan melalui berbagai eksplorasi anatomis, rasa, dan jiwa peserta secara individu dan keterhubungannya dengan individu lain, serta lingkungan. Peserta berlatih menggerakkan otot dan olah nafas, yang tidak lepas dari latar kultur masing-masing Setelah pertunjukan selesai, para peserta akan dipandu oleh dosen pendamping dalam menggali dan mengembangkan potensi dirinya. Kelompok dengan penampilan paling menarik mendapat penghargaan (rekognisi).

\section{Evaluasi dan Refleksi}

Evaluasi dan refleksi dikemas menjadi satu rangkaian kegiatan. Kegiatan ini dilakukan secara bersama oleh dosen dan mahasiswa, serta didukung oleh data catatan dari dosen. Dosen pendamping memfasilitasi kelebihan dan kekurangan mulai dari persiapan hingga pelaksanaan. Hasilnya ditampilkan dalam layar sehingga semua mahasiswa dan dosen pendamping dapat mengikutinya. Evaluasi dan refleksi akan menjadi pembelajaran bersama untuk merancang Kemeja selanjutnya. Mahasiswa merasa tidak terbebani karena semua jawaban dan pernyataan diakomodasi sepanjang relevan dengan kerangka kegiatan Kemeja (wawancara dengan Aditya Nur Hanafi, 9 Maret 2012).

Setelah evaluasi dan refleksi dilakukan penutupan dengan cara yang kreatif dan menyenangkan pula. Sekembali dari lapangan, peserta menyusun laporan per kelompok dan panitia membuat laporan sebagai dokumen bahan pembelajaranan bersama pelaksanaan Kemeja selanjutnya. Secara skematis, model pembelajaran Kemeja dapat dilihat pada bagan berikut : 


\section{Bagan 2 Model Kemeja}

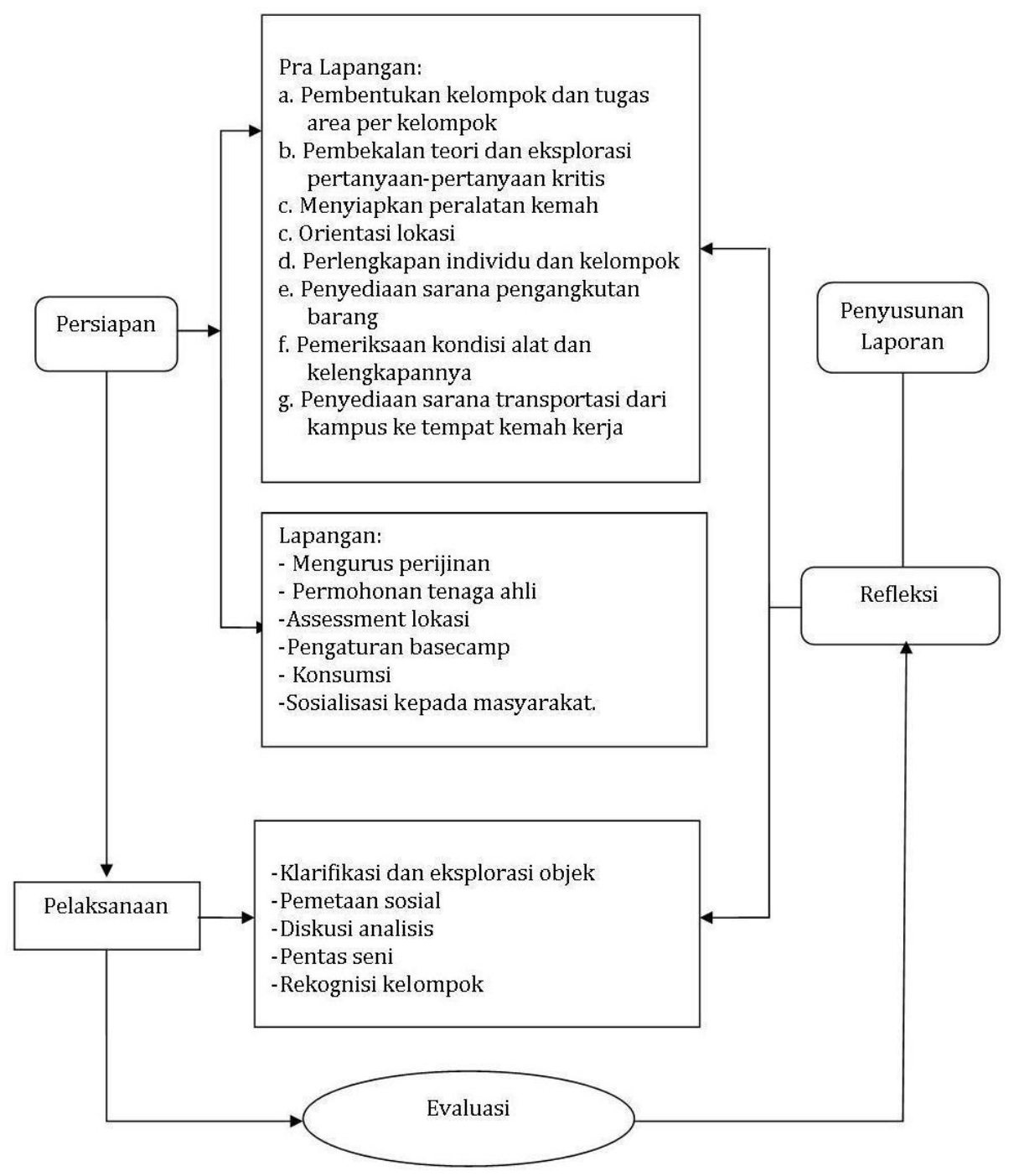

\section{Pembahasan}

Model Kemeja potensial untuk menjadi alternatif pembelajaran sejarah yang aktif, inovatif, kreatif, dan menyenangkan. Mahasiswa menjadi terbiasa berbuat segala sesuatu dengan mengerahkan segenap potensi dan beragam cara. Mahasiswa dan dosen terlibat aktif secara fisik, mental, emosional, bahkan moral dan spiritual.

Model kemeja memberikan pengalaman langsung sehingga belajar merupakan proses aktif mahasiswa dalam membangun pengetahuannya sendiri. Model Kemeja memberikan wewenang kepada mahasiswa untuk berpikir kritis 
secara bertanggung jawab, sedangkan dosen lebih banyak mendengar dan menghormati ide-ide mahasiswa, serta memberikan pilihan dan peluang kepada mahasiswa untuk mengambil keputusan sendiri. Proses belajar lebih mengembangkan motivasi intrinsik mahasiswa. Motivasi ini lebih bearti karena lebih murni dan langgeng serta tidak bergantung pada dorongan atau pengaruh orang lain.

Model Kemeja bersifat
inovatif. Pembelajaran menggunakan media/alat bantu terutama yang berbasis teknologi baru ke dalam pembelajaran sehingga terjadi renovasi mental, di antaranya membangun rasa pecaya diri. Penggunaan software multimedia, dan microsoft power point merupakan salah satu alternatif inovasi pembelajaran berbasis teknologi informasi. Inovasi pembelajaran yang tepat dan sesuai dengan kebutuhan dan perkembangan zaman untuk meningkatkan kemampuan kognitif, afektif, dan psikomotor.

Model Kemeja juga meru-pakan pembelajaran yang kreatif karena ada kreativitas dalam pengembangan kompetensi dan dalam pelaksanaan pembelajaran di kelas dan pemanfaatan objek peninggalan sejarah dan lingkungan sekitarnya sebagai sumber bahan dan sarana untuk belajar. Pembelajaran kreatif menciptakan kegiatan belajar yang beragam sehingga memenuhi berbagai tingkat kemampuan mahasiswa dan tipe serta gaya belajar mahasiswa. Mahasiswa pun kreatif dalam hal merancang kegiatan, melaksanakan dan membuat laporan.
Model Kemeja juga merupakan pembelajaran yang efektif. Banyak pengalaman dan hal baru yang diperoleh mahasiswa di lapangan. Dosen pun memperoleh pengalaman baru sebagai hasil interaksi multiaarah dengan mahasiswa dan lingkungan. Keefektifan pembelajaran dilakukan melalui evaluasi. Evaluasi disini bukan sekedar tes, tetapi refleksi, perenungan yang dilakukan oleh dosen dan mahasiswa, serta didukung oleh data catatan dosen.

Dosen menjadi pengajar yang efektif karena menjadi lebih menguasai materi; mengajar dan mengarahkan dengan memberi contoh; menghargai dan memotivasi mahasiswa; mengajarkan keterampilan pemecahan masalah; menggunakan metode yang bervariasi; mengembangkan pengetahuan pribadi; mengajarkan cara mempelajari sesuatu. Mahasiswa menjadi pembelajar yang efektif dalam arti menguasai pengetahuan dan kompetensi yang diperlukan dan mendapat pengalaman baru yang berharga.

Model Kemeja menciptakan suasana pembelajaran yang menyenangkan. Lingkungan yang rileks, menyenangkan, tidak membuat tegang (stress), aman, menarik, dan tidak membuat mahasiswa ragu melakukan sesuatu. Di lapangan tersedia materi pelajaran yang kaya dan beragam dan dapat menerapkan metode yang beragam pula yang melibatkana semua indera dan aktivitas otak. Situasi belajar yang menantang mahasiswa untuk berpikir jauh ke depan dan mengeksplorasi 
materi yang dipelajari, baik di kampus maupun di lapangan. Model Kemeja menciptakan situasi belajar emosional yang positif ketika para mahasiswa belajar bersama, ketika ada humor, dorongan semangat, waktu istirahat, dan dukungan yang antusias dari sesama mahasiswa dan dosen pandamping. Evaluasi dan refleksi membuat mahasiswa tidak terbebani, karena semua jawaban dan pernyataan akan diakomodasi sepanjang relevan dengan kerangka kegiatan Kemeja.

\section{Simpulan}

Model Kemeja pada dasamya mirip dengan studi wisata dan lawatan sejarah yaitu menekankan aktivitas serta kreativitas mahasiswa untuk mencari atau menemukan data kesejarahan dari suatu obyek sejarah. Model ini memungkinkan mahasiswa menemukan data yang lebih intensif dan bersifat menyeluruh dari peristiwa yang melatarbelakangi obyek tersebut. Untuk itu pelaksanaan kegiatannya dilakukan di suatu tempat tertentu dan berlangsung beberapa hari. Lokasi bersejarah itu biasanya tidak tersedia akomodasi maka peserta didik dapat tinggal di kemah-kemah, jadi tak ubahnya dengan suatu kegiatan perkemahan.

\section{Rancangan Model Kemeja} terdiri dari empat komponen kegiatan utama, yaitu persiapan, pelaksanaan, evaluasi dan refleksi, serta pelaporan. Tahap persiapan meliputi persiapan di kampus dan di lapangan, baik teknis maupun non teknis. Tahap pelaksanaan terdiri dari tiga kegiatan, yaitu klarifikasi dan eksplorasi objek, social mapping, diskusi analisis, dan pertunjukkan seni.

Model Kemeja potensial untuk menjadi alternatif pembelajaran sejarah yang aktif, inovatif, kreatif, efektif, dan menyenangkan dengan argumen dasar sebagai berikut.

a) Model kemeja memberikan pengalaman langsung sehingga belajar merupakan proses aktif mahasiswa dalam membangun pengetahuannya sendiri. Di perkemahan mahasiswa seakanakan sebagal sejarawansejarawan. Dalam konteks ini tidak hanya sikap penghayatan sejarah yang bisa dikembangkan, tapi juga beberapa aspek keterampilan penting terutama bekerja dengan tanggung jawab sendiri.

b) Model Kemeja inovatif karena menggunakan media/alat bantu berbasis teknologi baru sehingga terjadi renovasi mental.

c) Kreativitas dalam Kemeja tampak dalam pengembangan kompetensi dan dalam pembelajaran dengan pemanfaatan objek peninggalan sejarah dan lingkungan sekitarnya sebagai sumber bahan dan sarana untuk belajar.

d) Model Kemeja efektif karena dalam satu rangkai kegiatan banyak temuan baru dan pengalaman bermakna di lapangan.

e) Model Kemeja menciptakan suasana yang menyenangkan, rileks, tidak membuat tegang, aman, menarik, dan tidak membuat mahasiswa ragu melakukan sesuatu. 


\section{Saran}

Model Kemeja potensial untuk menjadi alternatif pembelajaran sejarah yang aktif, inovatif, kreatif, efektif, dan menyenangkan. Untuk itu para dosen pendidikan sejarah dan guru sejarah dapat mengembangkannya menjadi model pembelajaran sejarah sesuai dengan karakteristik peserta didiknya. Dukungan institusi, masyarakat, dan pengelola objek peninggalan sejarah sangat diperlukan dalam memfasilitasi pengembangan model kemah kerja sejarah. 


\section{DAFTAR PUSTAKA}

Abdullah, Taufik. 1995. Di Sekitar Peran Sejarah dan Tugas Sejarawan. Makalah pada Seminar Nasional Jurusan Sejarah FPIPS IKIP Yogyakarta, 30 April 1995.

Djahiri, A.K. 1993. Membina PIPS/PIS dan PPSyang Menjawab Tantangan Hari Esok. Jurnal Pendidikan llmu Sosial. I/1993. Bandung: Forum Komunikasi FPIPS/IPS Indonesia.

Friere, Paulo. 1984. Pendidikan Sebagai Praktek Pembebasan. Terjemah Alois N. Jakarta: Gramedia.

Hariyono. 1995. Mempelajari Sejarah Secara Efektif. Jakarta: Pustaka Jaya.

Jensen, Eric. 2007. Pembelajaran Berbasis Otak. Yogyakarta: Pustaka Belajar.

Kartodirdjo, Sartono. 1999. Ideologi dan Teknologi Dalam Pembangunan Bangsa Eksplorasi Dimensi Historis dan Sosio-Kultural. Jakarta: Penerbit Pebelan Jayakarta.

Milles, Mattew B \& A. Michael Huberman. Analisis Data Kualitatif. Terjemah Tjetjep Rohendi Rohidi. Jakarta: UI Press.

$\begin{array}{llr}\text { Moleong, } & \text { Lexy } & \text { J. 1990. Metode } \\ & \text { Penelitian } & \text { Kualitatif. } \\ \text { Bandung: } & \text { Remaja Rosda } \\ \text { Karya. } & & \end{array}$
Milles, Matthew B. dan A. Michael Huberman. 1992. Analisis
Data Kualitatif. Jakarta : UI Press.

Muclas Samani. 2007. Menggagas Pendidikan Bermakna. Surabaya : SIC

Nurjanto, 2007. "Wisata Sejarah sebagai Salah Satu Upaya Menelusuri Perjalanan Sejarah Bangsa." Makalah Peningkatan Pembinaan Kesadaran Sejarah bagi Generasi Muda. Subdin Kebudayaan Propinsi Jawa Tengah.

Soedjiarto. 1998. Pengajaran Sejarah

Sebagai Wahana Pendidikan Nilai dan Sikap. Makalah pada Simposium Pengajaran Sejarah Dirjen Kebudayaan, 25-28 Desember 1998 di Bogor Jawa Barat.

Suharto, Edi. Metode Dan Teknik

Pemetaan Sosial dalam http://www.policy.hu/su $\underline{\text { harto }}$ /modul a/makindo 18.ht m, diakses 3 April 2012.

Sumantri, Muh. Nu'man. 1996. Pendidikan IPS Ditinjau dari Perspektif Aktualisasinya. Jakarta: IKIP Jakarta.

Suryo, Djoko. 1993. Pelajaran Sejarah yang Baik Sebuah Catatan. Makalah Simposium Pengajaran Sejarah Direktorat Sejarah dan Nilai Tradisional Dirjen Kebudayaan, 8-11 Agustus 1993 di Pelabuhan Ratu, Sukabumi, Jawa Barat. 
Syah, Muhibbin \& Rahayu Kariadinata. 2009. "Pembelajaran Inovatif, Kreatif, Efektif Dan Menyenangkan (Paikem)" Bahan Pelatihan Pendidikan dan Latihan Profesi Guru (PLPG) Rayon Fakultas Tarbiyah dan Keguruan UIN Sunan Gunung Djati, Bandung, 2009.

Syaefudin, Udin. 2009. Inovasi

Pendidikan. Bandung: Alfabeta.

Utomo, Cahyo Budi. "Lawatan Sejarah sebagai Model Pembelajaran Sejarah." Makalah Seminar Nasional (Tidak Diterbitkan). Unnes: Semarang.

Wahab, Abdul Aziz. 2007. Metode dan Model-model Mengajar IPS. Bandung : Alfabeta.

Wasino, 2007. "Penelitian Sejarah di $\begin{array}{lr}\text { Kalangan } & \text { Siswa } \\ \text { Sebagai } & \text { Model } \\ \text { Pembelajaran } & \text { Sejarah } \\ \text { di Sekolah." } & \text { Makalah } \\ \text { Seminar } & \text { Nasional } \\ \text { (Tidak } & \text { Diterbitkan). } \\ \text { Unnes: Semarang. }\end{array}$ Widja, I Gde. 1988. Dasar-dasar Jakarta : Kencana Prenada Media Group.

Aktif, Zuhdi, Susanto. 2007. "Lawatan Sejarah sebuah Tawaran Metode Efektif untuk Pembelajaran Sejarah." Makalah Seminar Nasional (Tidak Diterbitkan). Unnes: Semarang.
Pengembangan Strategi dan Metode Pengajaran Sejarah. Singaraja : FKIP Universitas Udayana. . 2002. Menuju Wajah Baru
Pendidikan Sejarah. Yogyakarta : Laperra Pustaka Utama. 2008. Strategi Pembelajaran Berorientasi Standar Proses Pendidikan. 